\title{
LEGISLATION AND ITS ROLE IN IMPROVED UTILIZATION ${ }^{1}$
}

\section{BY J. G. SOMERS 2}

I was once asked what I would do if given the administration of another Branch of our Department in Manitoba. I said that the first thing I would do would be to limit, and if possible, abolish altogether from our vocabulary the all too frequently used term Law Enforcement.

I hope that you will not gather from that remark that I do not consider forest laws, or shall we say forest legislation, including legislation requiring certain utilization standards, as unnecessary. Legislation, of course, is very necessary and very important. However, I feel that in drafting forest legislation where local forest and other conditions govern so particularly what should be done, there is need to guard against making legislation so exacting and inflexible as to tie the bands of foresters and forest administrations to the point where they are unable to deal with varying conditions and situations in an appropriate manner.

Forest legislation, including legislation on utilization, in my opinion should be broad in scope, setting forth the general policy, principles and procedures to be followed, giving authority and leaving room for incorporation in agreements details of conditions and requirements deemed practical and desirable in the light of local forest and other conditions.

In Manitoba, and my remarks must of necessity refer to conditions as we find them in that Province, legislation pertaining to utilization covers only in a broad way what is required in the woods and is briefly as follows:

(1) Only such timber shall be cut as is marked or otherwise designated for removal by the Forest Officer, and all timber so marked or otherwise designated shall be cut and taken as operations progress.

(2) No unnecessary damage shall be done to young growth or to trees left standing.

(3) All merchantable portions shall be taken from trees cut and there shall be no unnecessary waste of timber.

(4) Stumps shall not be cut higher than 12 inches from the ground unless special permission in writing is obtained from the Forest Officer (usual practice stumps height not to exceed stump diameter).

(5) Timber unnecessarily wasted as the result of high stumps, large tops, improperly cut logs, together with lodged trees, skids, or logs not utilized, shall be estimated in feet board measure, cords, or lineal feet, and paid for at double the regulation rate of dues.

Other requirements are set out in the various timber sale and license agreements. In the drafting of such agreements the aim is to require that all timber, regardless of species, which should be removed from a silvicultural

\footnotetext{
${ }^{1}$ A paper presented at the 48 th Annual Meeting of the Canadian Institute of Forestry, held at Chicoutimi, Quebec, October 2 - 5, 1956.

2Provincial Forester, Department of Mines \& Natural Resources, Winnipeg, Man.
} 
or forestry point of view be taken with a minimum of waste, the timber cut to be manufactured into the product for which it is best suited, with due regard to economic and marketing conditions.

In some areas we may, for instance, dispose of white spruce saw timber, the principal product, only on the condition that poplar on the same area be utilized, or that any timber not suitable for lumber but suitable for poles, pulpwood, or fence posts be taken. In the case of sales where railway ties are the principal product we may require in some areas that slabs and tops be utilized as lumber or boxwood. On the other hand, in areas more remote such utilization requirements may be wholly impractical, and conditions such that single-purpose operations are permitted.

Under such circumstances it can be seen that the details of utilization requirements must be left to be covered in individual agreements.

So far I have referred only to utilization in the woods. There is, of course, the matter of utilization in manufacture.

In Manitoba we have no legislation setting forth definite requirements in manufacture. However, there is some need for this. There is a need particularly for legislation setting a minimum standard of milling equipment capable of producing properly sawn lumber with a minimum of waste. In Manitoba most sawlogs are produced by small operators, so that it is not practical as yet to require, for instance, that slabs be utilized as pulp. We do, however, in our sale agreements insist on certain requirements to minimize waste in lumber manufacture.

Consideration has been given from time to time to adopting cubic foot measure, as has been done by some of the other provinces, as an incentive to better utilization. Cost of scaling where most timber is produced by small operators is the main reason why we have been reluctant to go into this.

However, as an experiment very recently we put up a sale on a cubic foot basis, under which all trees to be cut were marked for removal, calipered, and the cubic volume computed. The purchaser will pay on the basis of cubic foot volume of standing timber to be cut regardless of product or products manufactured. This should be an inducement for the purchaser to get all he can from the timber sold and paid for. It remains to be seen whether or not this is a practical approach towards better utilization.

Legislation setting out the broad requirements in utilization is important. In the term Legislation, as referred to herein, I include Regulations under the Forest Act. 